\title{
ヒマワリの脂溶性画分に分布する抗菌活性物質について
}

(平成 6 年 6 月 16 日受理)

中野益男* 福島道広* 東 浩司*

\section{Isolation and Chemical Characterization of Antimicrobial Compounds from Sunflower (Helianthus annuus L.)}

\author{
Masuo Nakano, Michihiro Fukushima and Hiroshi Azuma \\ (Department of Bioresource Chemistry, Obihiro University of Agriculture and \\ Veterinary Medicine: Obihiro, Hokkaido 080, Japan)
}

\begin{abstract}
Sunflower roots, stem, leaves and receptacles were extracted with ethanol, and the oily ethanol extracts were partitioned into chloroform-methanol-water $(2: 2: 1.8$, by final vol.) by the Bligh-Dyer method to obtain the lipidic fraction in the organic phase. The antimicrobial activity of lipidic fractions were examined by the paper disk method, using $E$. coli and $C$. herbarum. The results showed that the lipidic fraction of receptacles contained the strongest antimicrobial activities against these two microorganisms. Four antimicrobial compounds were isolated and purified by silicic acid column chromatography, thin layer chromatography and $15 \% \mathrm{AgNO}_{3}$-thin layer chromatography. The structures of the antimicrobial compounds were determined by spectroscopic analysis, IR, MS, ${ }^{1} \mathrm{H}-\mathrm{NMR}$ and ${ }^{13} \mathrm{C}-\mathrm{NMR}$. The molecular weights and molecular formulas of the four compounds (1, 2, 3 and 4) were all 302 and $\mathrm{C}_{20} \mathrm{H}_{30} \mathrm{O}_{2}$, respectively, on the basis of the EI-high resolution MS. Examination of the IR and NMR spectra and degree of unsaturation suggested that these compounds were diterpenoic acids. By using ${ }^{1} \mathrm{H}$-NMR, ${ }^{13} \mathrm{C}$-NMR, DEPT, ${ }^{1} \mathrm{H}-{ }^{1} \mathrm{H}$-NMR and ${ }^{1} \mathrm{H}^{-13} \mathrm{C}$-NMR spectra, the chemical structure of 1 was determined to be trachyroban-19-oic acid. Similarly, the chemical structure of 2 was determined to be kaur-16-en-19-oic acid. The chemical structure of 4 was postulated to be beyer-15-en-19-oic acid on the basis of the NMR spectra.
\end{abstract}

(Received June 16, 1994)

Key words: ヒマワリ sunflower; 花托 receptacle; 抗菌活性 antimicrobial activity; 赤外吸光光 度法 infra-red absorption spectrometry (IR); 高分解能質量分析 high-resolution mass spectromery (HRMS); 核磁気共鳴分析 nuclear magnetic resonance (NMR); ジテルペノイド diterpenoide; トラキロバンカルボン酸 trachyloban-19-oic acid; カウレン酸 kaur-16-en-19-oic acid

\section{緒 言}

ヒマワリ(Helianthus annuus L.) は北アメリカ西部を 原産とする一年草で, 数千年前からアメリカインディア ンによる栽培と選抜が行われ，作物化されてきた，その 後，17 世紀にスペイン人によりヨーロッパに導入され， 当時は観賞用もしくは種子を菓子やコーヒ一の代用とし て用いるために栽培されていたが，しだいに油料作物と しての価值が高まった ${ }^{1)}$. しかし, 食用, 油脂原料に用い られるのは種子のみで, 他の部位は特に利用価値がない

\footnotetext{
* 帯広畜産大学生物資源化学科： $=080$ 北海道帯広市稲田町
}

\section{ために廃棄されてきた。}

Pyrek はヒマワリの花から 2 種類のジテルペノイド, trachyloban-19-oic acid, (-)-kaur-16-en-19-oic acid を単離した ${ }^{2}$. この二つの化合物はヒマワリの若芽及び 根からも単離されている3 ${ }^{3}$. Mitscher らはこれらの化合 物をヒマワリの茎加ら単離し，その抗菌活性を明らかに している4). また，ヒマワリガ (Homoemosome electellum) の幼虫に対する成長阻害効果も報告されてい る5).これらのジテルペノイドの他に, ヒマワリの地上部 若葉からは，ゲルマクラン骨格を有するセスキテルペン ラクトンであるアヌイトリンヘリアンゴリドが単離され 
ており，これらの化合物は抗菌作用や動物腫瘍の DNA/ RNA 合成に対する阻害作用を有するなど幅広い生理活 性を示すことが確かめられている ${ }^{6) ~ 8) . ~}$

今回, 著者らはヒマワリの種子を収獲した後の根, 茎, 葉及び花托（花床）の各部位に含まれる，抗菌活性を指 標とした新規の生理活性物質の検索及び単離を試みた。

\section{実験方法}

\section{1. 実験材料}

ヒマワリ (Helianthus annuus L.) は北海道北竜町で栽 培したIS-3001 を用い, 種子を採取した後に根, 茎, 葉 及び花托の各部位をそれぞれ採取した。

\section{2. 供試菌株及び培地}

供試菌株としては Cladosporium herbarum 9262, Escherichia coli ATCC11775 の 2 株を用いた. 培地は それぞれグルコース $50 \mathrm{~g}$, ペプトン $10 \mathrm{~g}$, 酵母エキス 1 $\mathrm{g}$, 寒天 $20 \mathrm{~g} / \mathrm{L}$ 及び肉エキス $5 \mathrm{~g}$, ペプトン $10 \mathrm{~g}$, 塩化 ナトリウム $2 \mathrm{~g}$ 及び寒天 $20 \mathrm{~g} / \mathrm{L}$ を使用した.

\section{3. 抗菌活性物質の単離}

ヒマワリ中の抗菌活性物質の単離・精製を Scheme 1 に示した. ヒマワリの根 $(9.0 \mathrm{~kg})$, 茎 $(15.0)$, 葉 $(14.2)$ 及 び花托 (9.4) は適当な大きさに切断し, エタノールで抽 出を行った. 各エタノール抽出物は, 更にBligh-Dyer 法9により脂溶性画分を得た。各脂溶性画分はカラムク
ロマトグラフィー (シリカゲル $30 \mathrm{~g}, 1.5 \times 30 \mathrm{~cm}$ ), 薄層 クロマトグラフィー (TLC) 及び $5 \% \mathrm{AgNO}_{3}$-TLC によ り単離・精製した。最終的に抗菌活性物質として 4 種類 (Compound 1, 2, 3 及び 4) を単離した.

\section{4. 抗菌活性の測定}

ペーパーディスク法を用いて抗菌活性を測定した。抗 菌活性試験は抗菌活性物質の単離・精製の各段階で行っ た.

\section{5. 抗菌活性物質のメチル誘導体}

試料のメチルェステル化は, Schlenk \& Gellerman の方法を用いて, $N$-methyl- $N$-nitroso- $p$-toluenesulfonamide $2.14 \mathrm{~g}$ を $30 \mathrm{ml}$ のエーテルに溶解後, $4 \%$ 水酸 化カリウムーエタノール溶液を $10 \mathrm{ml}$ 加え, 水浴 35 $40^{\circ}$ で蒸留し，ジアゾメタン/エーテル溶液を得た。この 溶液を試料に数摘加え, 室温で 10 分間放置してメチル 化反応を行った ${ }^{10)}$.

\section{6. 分析方法}

赤外吸光スペクトル (IR) は日本分光社製 A-100を用 いて， $\mathrm{KBr}$ 法により分析した。 質量スペクトル (MS) は クレイトス社製 H-1 を用いて, 直接導入法により分析し た. 分析条件はイオンモード, EI; イオン化源, $70 \mathrm{eV}$; イオン化温度, $180^{\circ}$; 分解能, 10,000 で行った. ${ }^{1} \mathrm{H}-$ 及 び ${ }^{13} \mathrm{C}$ - 核磁気共鳴スペクトル $\left({ }^{1} \mathrm{H}-\mathrm{NMR},{ }^{13} \mathrm{C}-\mathrm{NMR}\right)$ は

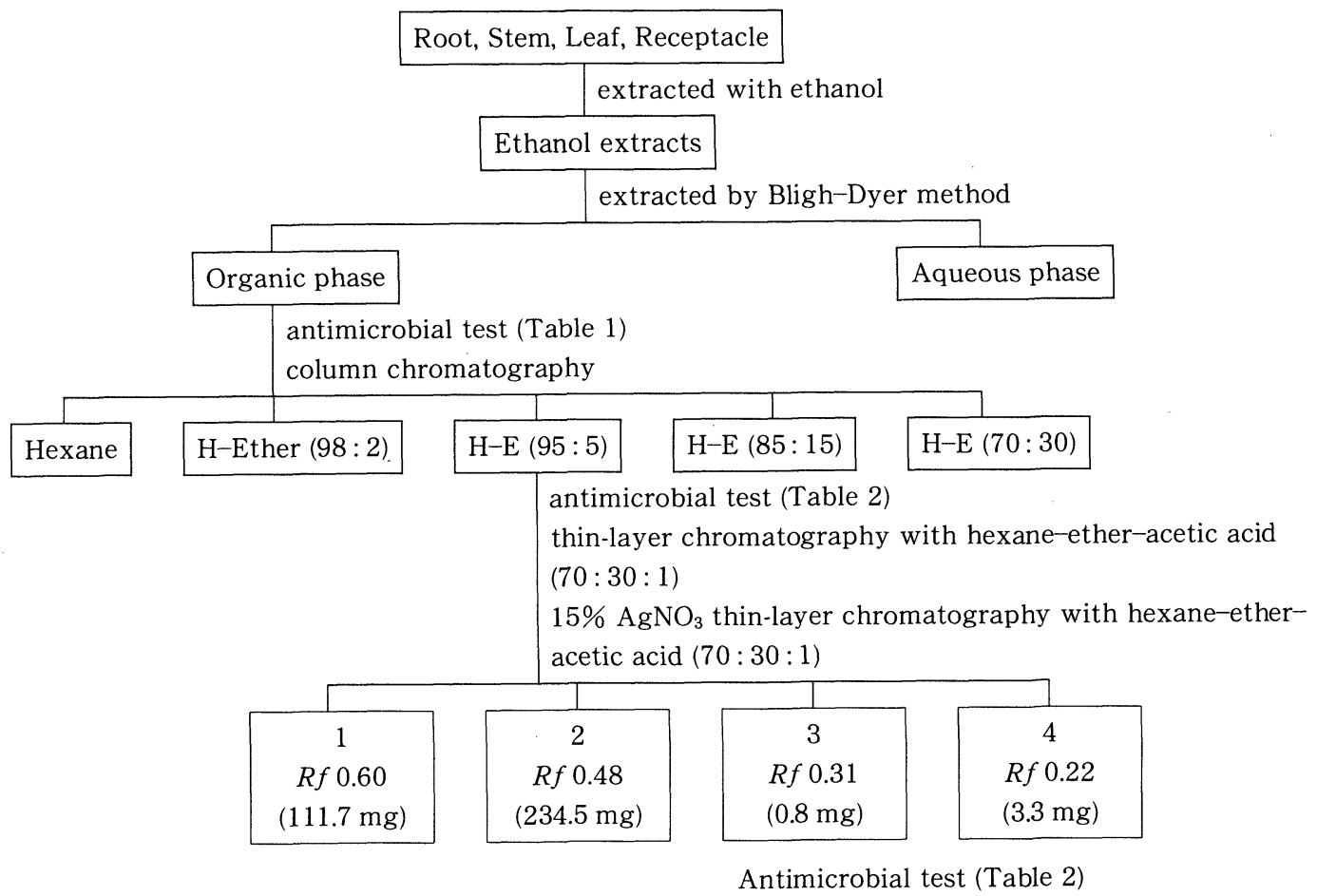

Scheme 1. Isolation procedure of antimicrobial compounds from sunflower ( ): extract volume 
JEOL EX-270 (270 MHz) を用いて, ${ }^{1} \mathrm{H},{ }^{13} \mathrm{C},{ }^{1} \mathrm{H}^{-1} \mathrm{H},{ }^{1} \mathrm{H}-$ ${ }^{13} \mathrm{C}$ - 二次元 NMR スペクトル，DEPT を測定した。測定 溶媒には $\mathrm{CDCl}_{3}$ を用いた。 その $\mathrm{CDCl}_{3}$ のスペクトルを 内部標準として用い，化学シフトは $\delta \mathrm{ppm}$ で表した。

1: Crystal, mp 164 166 ; IR (KBr), 3,425, 3,020, 2,995, 2,930, 2,860, 1,698 (-COOH), 1,470, 1,445, 1,408, $1,260(-\mathrm{COOH}) \mathrm{cm}^{-1}$; MS, $m / z 302(76 \%), 287(41)$, 257 (16), 246 (100), 231 (47), 220 (10), 201 (14); ${ }^{1} \mathrm{H}-$ NMR $\left(\mathrm{CDCl}_{3}\right) \delta: 0.57(1 \mathrm{H}, \mathrm{dd}, J=3$ and $3 \mathrm{~Hz}, \mathrm{H}-12)$, $0.82(1 \mathrm{H}, \mathrm{m}, \mathrm{H}-13), 0.87$ (3 H, s, H-20), $0.98(1 \mathrm{H}, \mathrm{dd}$, $J=11$ and $11 \mathrm{~Hz}, \mathrm{H}-5), 1.12(3 \mathrm{H}, \mathrm{s}, \mathrm{H}-17), 1.18(2 \mathrm{H}, \mathrm{d}$, $J=1 \mathrm{~Hz}, \mathrm{H}-14), 1.21$ (3 H, s, H-18), 1.25 (2 H, s, H-15), $1.75(2 \mathrm{H}, \mathrm{m}, \mathrm{H}-16)$.

1 ×チルエステル: Crystal, mp 98 100 ; IR (KBr), $3,420,3,005,2,990\left(-\mathrm{CH}_{3}\right), 2,925\left(-\mathrm{CH}_{2}-\right), 2,900(-\mathrm{C}-\mathrm{H})$, $2,860\left(-\mathrm{CH}_{3}\right), 2,845\left(-\mathrm{CH}_{2}-\right), 1,722(-\mathrm{C}=\mathrm{O}), 1,680(-\mathrm{C}=$ O), 1,465 $\left(-\mathrm{COOCH}_{3},-\mathrm{CH}_{2}^{-}\right), 1,170,1,160(-\mathrm{C}-\mathrm{O}-)$, $1,145(-\mathrm{C}-\mathrm{O}-), 1,090,1,040,982\left(\mathrm{C}_{6} \mathrm{H}_{12}\right), 970\left(\mathrm{C}_{6} \mathrm{H}_{12}\right)$ $\mathrm{cm}^{-1}$; MS, $m / z 316\left(\mathrm{M}^{+} 86 \%\right), 301$ (41), 274 (13), 260 (100), 257 (56), 245 (20), 241 (36), 229 (8), 201 (20); EI-HRMS, MW316. $23731 \quad\left(\mathrm{C}_{21} \mathrm{H}_{32} \mathrm{O}_{2}\right.$ calcd. 316 . 24584).

2: Crystal, mp 169 170 ; IR (KBr), 3,420, 3,070 $(-\mathrm{C}=\mathrm{C}-), 2,935,2,855,1,698(-\mathrm{COOH}), 1,660(-\mathrm{C}=\mathrm{C}-)$, $1,470,1,445,1,410,1,365,1,320,1,260(-\mathrm{COOH}) \mathrm{cm}^{-1}$; MS, $m / z 302$ (71\%), 287 (65), 269 (10), 259 (59), 243 (42), 231 (26), 219 ((23), 205 (10), 131 (100), 119 (98); ${ }^{1} \mathrm{H}-\mathrm{NMR}\left(\mathrm{CDCl}_{3}\right) \delta: 0.81(2 \mathrm{H}, \mathrm{ddd}, J=14,13$ and $4 \mathrm{~Hz}$, $\mathrm{H}-1), 0.95(3 \mathrm{H}, \mathrm{s}, \mathrm{H}-20), 1.14(2 \mathrm{H}, \mathrm{dd}, J=12$ and $5 \mathrm{~Hz}$, H-14), 1.24 (3 H, s, H-18), 1.46 (2 H, br. s, H-12), 1.50 (2 $\mathrm{H}, \mathrm{d}, J=12 \mathrm{~Hz}, \mathrm{H}-17), 1.84(2 \mathrm{H}, \mathrm{m}, \mathrm{H}-6), 2.05(2 \mathrm{H}, \mathrm{s}, \mathrm{H}-$ 15), 2.64 (1 H, br. s, H-13), 4.76 (2 H, br. s, H-17).

2 メチルエステル: Crystal, mp 73 74 ${ }^{\circ}$; IR (KBr), 3,420, 3,060 $\left(=\mathrm{CH}_{2}\right), 2,990\left(-\mathrm{CH}_{3}\right), 2,945\left(-\mathrm{CH}_{3}\right), 2,930$ $\left(-\mathrm{CH}_{2}-\right), 2,900(-\mathrm{C}-\mathrm{H}), 2,875\left(-\mathrm{CH}_{3}\right), 2,850\left(-\mathrm{CH}_{2}-\right)$, $1,780\left(=\mathrm{CH}_{2}\right), 1,720(-\mathrm{C}=\mathrm{O}), 1,360,1,3301,270(-\mathrm{C}-$ O), 1,235 (-C-O), $1,200(-\mathrm{C}-\mathrm{O}), 1,190(-\mathrm{C}-\mathrm{O}), 1,165$ $(-\mathrm{C}-\mathrm{O}), 1,150(-\mathrm{C}-\mathrm{O}), 1,125,1,110,1,090,1,040,1,020$ $\left(\mathrm{C}_{6} \mathrm{H}_{12}\right), 1,000,985\left(=\mathrm{CH}_{2}\right), 965 \cdot\left(\mathrm{C}_{6} \mathrm{H}_{12}\right), 950,915$ (= $\left.\mathrm{CH}_{2}\right), 890\left(=\mathrm{CH}_{2}\right) \mathrm{cm}^{-1}$; MS, $m / z 316\left(\mathrm{M}^{+} 31 \%\right), 301$ (22), 273 (56), 257 (72), 241 (63), 213 (28); EI-HRMS, MW 316. $23763\left(\mathrm{C}_{21} \mathrm{H}_{32} \mathrm{O}_{2}\right.$ calcd. 316. 24584).

3: Oil; IR (KBr), 3,400, 2,920 (- $\left.-\mathrm{CH}_{2}{ }^{-}\right), 2,850\left(-\mathrm{CH}_{2}{ }^{-}\right)$, $1,610(-\mathrm{C}=\mathrm{O}), 1,550\left(-\mathrm{COO}^{-}\right), 1,465\left(-\mathrm{CH}_{2}-\right), 1,445$ $\left(-\mathrm{CH}_{2}-\right), 1,410(-\mathrm{COOH}), 1,380\left(-\mathrm{CH}_{3}\right), 1,050,1,020$ $\left(\mathrm{C}_{6} \mathrm{H}_{12}\right), 940$ (-COOH) cm ${ }^{-1}$; MS, $m / z 302(38 \%), 287$ (33), 259 (16), 241 (12), 231 (5), 213 (10), 187 (35), 167 (40), 149 (100), 131 (14), 119 (31).

3 ×チルエステル: Oil; MS, $m / z 316\left(\mathrm{M}^{+} 22 \%\right), 301$
(10), 273 (10), 257 (10), 241 (19), 207 (14), 187 (34), 167 (28), 149 (100), 131 (12), 119 (21); EI-HRMS, MW316.23875 $\left(\mathrm{C}_{21} \mathrm{H}_{32} \mathrm{O}_{2}\right.$ calcd. 316.24584).

4: Oil; IR (KBr), 3,420, 3,040 (C=C), 3,200, 2,950 $\left(-\mathrm{CH}_{3}\right), 2,930\left(-\mathrm{CH}_{2}-\right), 2,850\left(-\mathrm{CH}_{2}-\right), 1,698(-\mathrm{COOH})$, $1,462\left(-\mathrm{CH}_{2}-\right), 1,450\left(-\mathrm{CH}_{2}-\right), 1,405(-\mathrm{COOH}), 1,363$ $\left(-\mathrm{CH}_{3}\right), 1,320\left(=\mathrm{CH}_{2}\right), 1,270(-\mathrm{COOH}), 1,255(-\mathrm{C}-\mathrm{O}-)$, $1,230,1,210(-\mathrm{COOH}), 1,190,1,160,1,120,1,090,1,070$, 1,035, 1,010, $970\left(\mathrm{C}_{6} \mathrm{H}_{12}\right), 920(-\mathrm{COOH}), 845(\mathrm{C}=\mathrm{C})$, 790, 750, $740\left(-\left(\mathrm{CH}_{2}\right)_{\mathrm{n}}-\right) \mathrm{cm}^{-1}$; MS, $m / z 302$ (13\%), 293 (19), 281 (13), 269 (10), 255 (13), 243 (23), 231 (21), 219 (23), 205 (10), 193 (16), 181 (77), 169 (55), 131 (97), 119 (100); ${ }^{1} \mathrm{H}-\mathrm{NMR}\left(\mathrm{CDCl}_{3}\right) \delta$ : 0.67 (3 H, s, H-20), 1.00 (3 $\mathrm{H}, \mathrm{s}, \mathrm{H}-18), 1.25$ (3 H, s, H-17), $5.46(1 \mathrm{H}, \mathrm{d}, J=5.5 \mathrm{~Hz}, \mathrm{H}-$ 15), $5.73(1 \mathrm{H}, \mathrm{d}, J=5.5 \mathrm{~Hz}, \mathrm{H}-16)$.

4 メチルエステル: Oil; MS, $m / z 316\left(\mathrm{M}^{+} 86 \%\right), 301$ (9), 273 (5), 257 (21), 241 (11), 227 (4), 194 (23), 181 (24), 148 (40), 135 (100), 122 (69), 105 (61), 93 (60).

\section{結果及び考察}

\section{1. 抗菌活性}

ヒマワリの各部位から抽出した脂溶性画分の抗菌活性 をTable 1 に示した. 茎の画分には抗菌活性物質がほと んど存在しなかった。その他の部位に㧍ける活性は花 托, 根, 葉の順であった。 また, E. coli ょりもC. herbarum に対して比較的強い活性を持つ傾向が見られた。 そ こで活性が最も高かった花托の脂溶性画分における抗菌 活性物質の単離・精製を行った. 各単離・精製段階での 抗菌活性試験の結果を Table 2 に示した。へキサンー エーテル $(95: 5, \mathrm{v} / \mathrm{v})$ 画分に抗菌活性が見られ，この画 分を $15 \% \mathrm{AgNO}_{3}$ - TLC (ヘキサンーエーテルー酷酸, 70 : $30: 1, \mathrm{v} / \mathrm{v} / \mathrm{v})$ で分画した結果, $R f$ 值 $0.60(\mathbf{1}), 0.48(\mathbf{2})$, 0.31 (3), 0.22 (4) にそれぞれスポットが確認され, すべ てに抗菌活性が見られた。特に 2 に強い活性が見られ た.

Table 1. Antimicrobial Activity of Sunflower Extracts

\begin{tabular}{lcc}
\hline \hline \multirow{2}{*}{ Extract } & \multicolumn{2}{c}{ Inhibited zone $(\mathrm{mm})^{\mathrm{a}}$} \\
\cline { 2 - 3 } & C. herbarum & E. coli \\
\hline Root & 8.4 & 8.0 \\
Stem & 6.2 & 6.2 \\
Leaf & 7.8 & 7.4 \\
Receptacle & 9.0 & 8.0 \\
Control $^{\mathrm{b}}$ & - $^{\mathrm{c}}$ & - \\
\hline
\end{tabular}

${ }^{a}$ By paper disk method $1 \mathrm{mg} /$ disk (6 $\mathrm{mm}$ thin)

${ }^{b}$ Chloroform-methanol $(2: 1, \mathrm{v} / \mathrm{v})$

${ }^{c}$ No inhibition 
Table 2. Antimicrobial Activity of Each Fraction from the Receptacle

\begin{tabular}{ccc}
\hline \hline \multirow{2}{*}{ Fraction } & \multicolumn{2}{c}{ Inhibition zone $(\mathrm{mm})$} \\
\cline { 2 - 3 } & C. herbarum & E. coli \\
\hline Column chromatography & & \\
Hexane fr. & $-\mathrm{b}$ & - \\
H-Ether $(98: 2) \mathrm{fr}$. & - & - \\
H-E $(95: 5) \mathrm{fr}$. & - & 7.4 \\
H-E $(85: 15) \mathrm{fr}$. & - & - \\
H-E $(70: 30)$ fr. & - & - \\
$15 \%$ AgNO & thin-layer chromatography & \\
$\mathbf{1}(R f 0.60)$ & 9.0 & 7.2 \\
$\mathbf{2}(R f 0.48)$ & 9.8 & 8.2 \\
$\mathbf{3}(R f 0.31)$ & 8.4 & 6.8 \\
$\mathbf{4}(R f 0.22)$ & 9.2 & 7.0 \\
Control & - & - \\
\hline
\end{tabular}

a, c By paper disk method $1 \mathrm{mg} /$ disk, $0.1 \mathrm{mg} /$ disk (6 $\mathrm{mm}$ thin) respectively

b No inhibition

d Chloroform-methanol $(2: 1, \mathrm{v} / \mathrm{v})$

\section{2. 抗菌活性物質の構造解析}

$1(R f 0.60)$ 及び 1 メチルェステルの IR スペクトルは それらが脂環式の物質であり，かつカルボキシル基が存 在することを示している. 3,000 及び $1,600 \mathrm{~cm}^{-1}$ 付近 の吸収から炭素鎖内に二重結合は存在しないと考えられ る. 1 のIR スペクトルにおける 1,698 及び $1,260 \mathrm{~cm}^{-1}$ の吸収はカルボン酸の存在を示している，1メチルエス テルのMSスペクトルより分子量は 316 , 分子式は $\mathrm{C}_{21} \mathrm{H}_{32} \mathrm{O}_{2}$ であることが確認された. ${ }^{13} \mathrm{C}-\mathrm{NMR}$ スペクト ルよりカルボキシル炭素が一つ存在することが明らかな ので, 1 の分子量は 302 , 分子式は $\mathrm{C}_{20} \mathrm{H}_{30} \mathrm{O}_{2}$ と推定され た. 分子式より 1 の不飽和数は 6 個であり, 1 個はカル ボキシル基の $\mathrm{C}=\mathrm{O}$ であるため, また, IR 及び ${ }^{1} \mathrm{H}-$ $\mathrm{NMR},{ }^{13} \mathrm{C}-\mathrm{NMR}$ スペクトルより, 炭素鎖内二重結合は 存在しないので残りの 5 個の不飽和数はすべて飽和し た環に相当することが示唆された. ${ }^{1} \mathrm{H},{ }^{13} \mathrm{C},{ }^{1} \mathrm{H}-{ }^{1} \mathrm{H},{ }^{1} \mathrm{H}-$ ${ }^{13} \mathrm{C}$-二次元 NMR スペクトル， DEPT による測定の結果 から， 1 は 3 個のメチル基 $\left(\delta_{\mathrm{H}} 0.87(\mathrm{H}-20), 1.12(\mathrm{H}-17)\right.$, $\left.1.21(\mathrm{H}-18), \delta_{\mathrm{C}} 12.44,20.54,28.84\right)$ を持ち, それらはす ベて 4 級炭素に結合することが示された． $\delta_{\mathrm{C}} 183.52$ の シグナルは 4 級炭素のカルボキシル基の炭素で, $\delta_{\mathrm{H}}$ 10.96 の幅広い弱いシグナルはそれがカルボン酸である ことを示唆している. $\delta_{\mathrm{C}} 20.54$ のシグナルはその強度か ら 2 個の炭素のシグナルが重なったものと思われる.そ のうちの炭素の一つは先に述べた 3 個のメチル基のう ちの一つに相当し，もう一つのシグナルは DEPTより メチン基であることが示された。 $\delta_{\mathrm{H}} 0.57$ (H-12) のシグ ナルは, このメチン基のプロトンのあのであり, その化
Table 3. ${ }^{13} \mathrm{C}$-NMR Spectral Data of $\mathbf{1}\left(\mathrm{CDCl}_{3}\right)$

\begin{tabular}{crlr}
\hline Carbon & \multicolumn{1}{c}{$\mathbf{1}$} & \multicolumn{1}{c}{ DEPT } & Ref. 12 \\
\hline C- 1 & 39.41 & $\mathrm{CH}_{2}$ & 39.5 \\
C- 2 & 18.67 & $\mathrm{CH}_{2}$ & 18.7 \\
C- 3 & 37.85 & $\mathrm{CH}_{2}$ & 37.8 \\
C- 4 & 43.60 & $\mathrm{C}$ & 43.7 \\
C- 5 & 56.93 & $\mathrm{CH}$ & 57.0 \\
C- 6 & 21.71 & $\mathrm{CH}_{2}$ & 21.8 \\
C- 7 & 39.19 & $\mathrm{CH}_{2}$ & 39.2 \\
C- 8 & 40.72 & $\mathrm{C}$ & 40.8 \\
C- 9 & 52.72 & $\mathrm{CH}$ & 52.8 \\
C-10 & 38.87 & $\mathrm{C}$ & 38.9 \\
C-11 & 19.71 & $\mathrm{CH}$ & 19.7 \\
C-12 & 20.54 & $\mathrm{CH}_{2}$ & 20.6 \\
C-13 & 24.24 & $\mathrm{CH}^{2}$ & 24.3 \\
C-14 & 33.10 & $\mathrm{CH}_{2}$ & 33.1 \\
C-15 & 50.33 & $\mathrm{CH}_{2}$ & 50.4 \\
C-16 & 22.39 & $\mathrm{C}$ & 22.4 \\
C-17 & 20.54 & $\mathrm{CH}_{3}$ & 20.6 \\
C-18 & 28.84 & $\mathrm{CH}_{3}$ & 28.9 \\
C-19 & 183.52 & $\mathrm{C}$ & 184.7 \\
C-20 & 12.44 & $\mathrm{CH}_{3}$ & 12.5 \\
\hline
\end{tabular}

学シフト值からシクロプロピル基を形成していることが 示唆された. $\delta_{\mathrm{H}} 0.57$ (H-12) のシグナルは $\delta_{\mathrm{H}} 0.82(\mathrm{H}-13)$ のシグナルとカップリングしている. $\delta_{\mathrm{H}} 0.82$ (H-13) の シグナルは更に $\delta_{\mathrm{H}} 1.18$ (H-14) のシグナルとカップリン グしている. また, $\delta_{\mathrm{H}} 1.25$ (H-15) のシグナルはどのシグ ナルともカップリングしていないので隣にプロトンが存 在しないと思われる。 $\delta_{\mathrm{H}} 0.98(\mathrm{H}-5)$ のシグナルは $\delta_{\mathrm{H}}$ 1.75 (H-6) のシグナルとカップリングしている. 以上の IR, MS, NMR スペクトルと五環性ジテルペン酸関連化 合物の文献值 ${ }^{2), 4)}$ 及び ${ }^{13} \mathrm{C}-\mathrm{NMR}$ の值 ${ }^{11), 12)}$ とほぼ一致し ていたことから，1 は trachyloban-19-oic acid と同定 された (Table 3, Fig. 1a).

$2(R f 0.48)$ 及び 2 メルェステルのIR スペクトルは 1 のそれと類似しており, 同様の物質であることを示唆 している.しかし，2メチルエステルのIR スペクトルに おける 3,060 及び $1,780,985 \mathrm{~cm}^{-1}$ の吸収は末端二重結 合の存在を示している. 1 メチルエステルと同様に 2 メ チルエステルの MS スペクトルより分子量は 316 , 分子 式は $\mathrm{C}_{21} \mathrm{H}_{32} \mathrm{O}_{2}$ であることが確認された. ${ }^{13} \mathrm{C}-\mathrm{NMR}$ スペ クトルよりカルボキシル炭素が一つ存在していることが 明らかなので, 2 の分子量は 302 , 分子式は $\mathrm{C}_{20} \mathrm{H}_{30} \mathrm{O}_{2}$ で あると決定された. 分子式より不飽和数は 6 個であり, 1 個はカルボキシル基の $\mathrm{C}=\mathrm{O}$ であると推定される。 ま た, ${ }^{13} \mathrm{C}-\mathrm{NMR}$ スペクトルより二重結合が 1 個存在する と推定されるので， 2 は 4 個の飽和した環を持つと考え られる, ${ }^{1} \mathrm{H},{ }^{13} \mathrm{C},{ }^{1} \mathrm{H}-{ }^{1} \mathrm{H},{ }^{1} \mathrm{H}-{ }^{13} \mathrm{C}$-二次元 NMR スペクト ル，DEPT による測定の結果から， 2 は 2 個のメチル基 

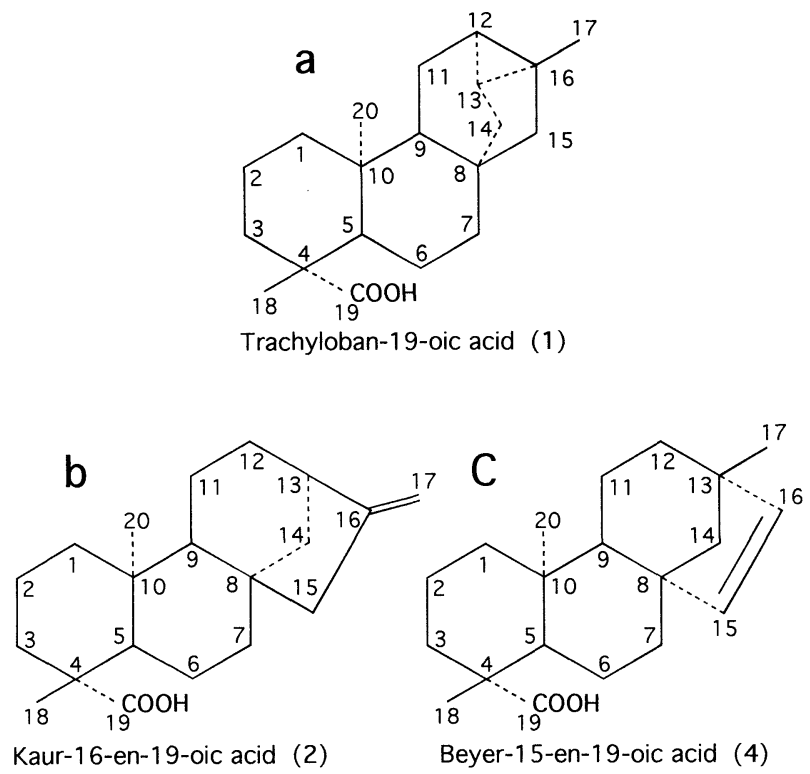

Fig. 1. Chemical structure of antimicrobial compounds
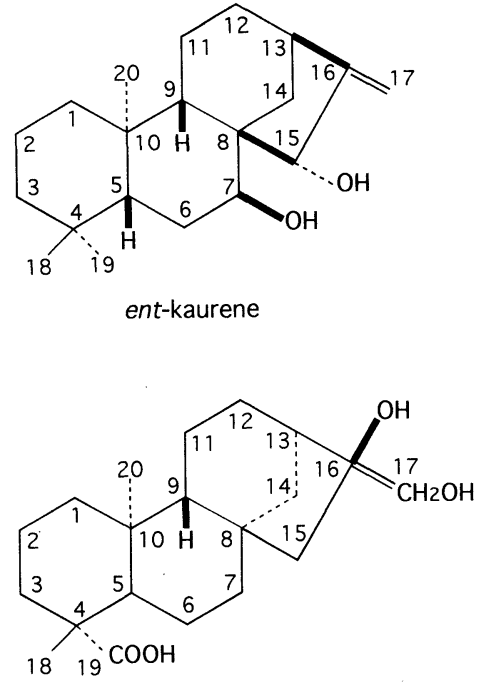

16ק, 17-dihydroxykauran-19-oic acid

Fig. 2. Chemical structure of ent-kaurene and $16 \beta, 17$-dihydroxykauran-19-oic acid

$\left(\delta_{\mathrm{H}} 0.95(\mathrm{H}-20), 1.24(\mathrm{H}-18), \delta_{\mathrm{C}} 15.58,28.95\right)$ を持つこと が示された. $\delta_{\mathrm{C}} 183.88$ のシグナルは 4 級炭素のあので あり，化学シフト值からカルボキシル基の炭素であると 思われる. $\delta_{\mathrm{H}} 11.35$ の幅広い弱いシグナルはそれがカル ボン酸であることを示唆している. $\delta_{\mathrm{c}} 102.97,155.92$ の シグナルは二重結合を形成する炭素で, $\delta_{\mathrm{C}} 102.97$ のシ グナルは 4 級炭素であり, $\delta_{\mathrm{C}} 155.92$ のシグナルはメチ
レン基であることから末端二重結合の存在が示された。 $\delta_{\mathrm{H}} 4.76$ (H-17) のシグナルは末端メチレン基のあのであ ることは明らかで, $\delta_{\mathrm{H}} 2.05$ (H-15) のシグナルとカップ リングしている. $\delta_{\mathrm{H}} 2.64(\mathrm{H}-13)$ のシグナルは化学シフ 卜值から末端二重結合を形成する炭素に隣接する炭素の プロトンであると思われる. また，これは $\delta_{\mathrm{H}} 1.14(\mathrm{H}-14)$ のシグナル及び $\delta_{\mathrm{H}} 1.46(\mathrm{H}-12)$ のシグナルとカップリン グしている. $\delta_{\mathrm{H}} 1.50(\mathrm{H}-7)$ のシグナルは $\delta_{\mathrm{H}} 1.84(\mathrm{H}-6)$ の シグナルとカップリングしている. IR, MS, NMR スペ クトルと四環性ジテルペン酸の文献值 ${ }^{2), 4), 13)}$, 及び類縁 化合物である ent-kaurene $\left(\mathrm{C}_{20} \mathrm{H}_{32} \mathrm{O}_{2}\right)^{14)}, 16 \beta, 17$-dihydroxykauran-19-oic acid $\left(\mathrm{C}_{20} \mathrm{H}_{32} \mathrm{O}_{4}\right)^{15)}$ (Fig. 2) の ${ }^{13} \mathrm{C}-\mathrm{NMR}$ と比較することにより，2 は kaur-16-en-19oic acid であると同定された (Table 4, Fig. 1b).

$3(R f 0.31)$ は, IR, MS スペクトル及びメチルエステ ル化誘導体の分子量 316 から分子量 302 のカルボン酸 であることが分かった。

$4(R f$ 0.22) は, IR, MS スペクトルから分子量 302 の カルボン酸であると思われ, ${ }^{13} \mathrm{C}-\mathrm{NMR}$ スペクトルより 炭素数は 20 個の $\mathrm{C}_{20} \mathrm{H}_{30} \mathrm{O}_{2}$ であると推測される. ${ }^{1} \mathrm{H}$ NMR， ${ }^{13} \mathrm{C}-\mathrm{NMR}$ スペクトル， DEPT, ${ }^{1} \mathrm{H}^{-1} \mathrm{H}$-二次元 NMR スペクトルによる測定の結果から，3個のメチル 基 $\left(\delta_{\mathrm{H}} 0.67(\mathrm{H}-20), 1.00(\mathrm{H}-18), 1.25(\mathrm{H}-17), \delta_{\mathrm{C}} 14.25\right.$, 25.34, 29.56) を持つことが示された. また, カルボキシ ル基の炭素のシグナルが $\delta_{\mathrm{c}} 183.18$ にみられ, 1 3 と同 様にカルボン酸であると考えられる. $\delta_{\mathrm{C}} 135.24$ 及び 136.96 にみられるシグナルは化学シフト值から二重結 合を形成する炭素のものであり，分子内に二重結合が一 
Table 4. ${ }^{13} \mathrm{C}-\mathrm{NMR}$ Spectral Data of $2\left(\mathrm{CDCl}_{3}\right)$

\begin{tabular}{|c|c|c|c|c|}
\hline Carbon & 2 & DEPT & Ref. 14 & Ref. 15 \\
\hline C- 1 & 40.68 & $\mathrm{CH}_{2}$ & 40.5 & 41.3 \\
\hline C- 2 & 19.09 & $\mathrm{CH}_{2}$ & 18.9 & 18.9 \\
\hline C- 3 & 37.81 & $\mathrm{CH}_{2}$ & 42.2 & 38.0 \\
\hline C- 4 & 44.22 & $\mathrm{C}$ & 33.3 & 43.5 \\
\hline C. 5 & 57.02 & $\mathrm{CH}$ & 56.2 & 56.9 \\
\hline C- 6 & 21.82 & $\mathrm{CH}_{2}$ & 20.4 & 21.7 \\
\hline C- 7 & 41.26 & $\mathrm{CH}_{2}$ & 41.3 & 40.8 \\
\hline C- 8 & 43.69 & $\mathrm{C}$ & 44.3 & 43.4 \\
\hline C- 9 & 55.08 & $\mathrm{CH}$ & 56.1 & 56.3 \\
\hline C- 10 & 39.64 & $\mathrm{C}$ & 39.5 & 39.4 \\
\hline C-11 & 18.42 & $\mathrm{CH}_{2}$ & 18.3 & 19.0 \\
\hline C-12 & 33.10 & $\mathrm{CH}_{2}$ & 33.5 & 26.8 \\
\hline C-13 & 43.83 & $\mathrm{CH}$ & 44.3 & 40.1 \\
\hline C-14 & 39.68 & $\mathrm{CH}_{2}$ & 40.0 & 37.5 \\
\hline C-15 & 48.95 & $\mathrm{CH}_{2}$ & 49.5 & 52.4 \\
\hline C-16 & 155.92 & $\mathrm{C}$ & 155.8 & 79.7 \\
\hline C-17 & 102.97 & $\mathrm{CH}_{2}$ & 103.4 & 69.5 \\
\hline C-18 & 28.95 & $\mathrm{CH}_{3}$ & 33.7 & 179.3 \\
\hline C-19 & 183.88 & $\mathrm{C}$ & 21.2 & 29.0 \\
\hline C-20 & 15.82 & $\mathrm{CH}_{3}$ & 17.7 & 15.1 \\
\hline
\end{tabular}

つ存在することになる。 H-NMR, ${ }^{1} \mathrm{H}-{ }^{1} \mathrm{H}$ - 二次元 NMR スペクトルにおける $\delta_{\mathrm{H}} 5.46$ (H-15) 及び $\delta_{\mathrm{H}} 5.73(\mathrm{H}-16)$ のシグナルは二重結合を形成する炭素のプロトンである と思われ，お互いにカップリングする以外は他のシグナ ルとカップリングしていないので二重結合は 4 級炭素 に挟まれていると考えられる，その他，DEPTによるメ チル基, メチレン基及びメチン基の個数, ${ }^{13} \mathrm{C}-\mathrm{NMR}$ の化 学シフト值から 4 は beyer-15-en-19-oic acid であると 推測される (Table 5, Fig. 1c).

以上の結果, ヒマワリの根, 茎, 葉及び花托の脂溶性 成分に抗菌活性を見いだした，特に花托に最も高い活性 がみられ, 脂溶性成分についても最も多く抽出されてい た（根, 3.35\%；茎, $0.92 \%$ ；葉，3.73\%；花托，4.53\%). 抗菌活性物質であるジテルペノイドの量的関係は明らか にしていないが，その抽出量む花托で最む多いと推察さ れる (Table 1)。このことは, 以前の報告2) 4) で, ヒマワ リの若芽, 根及び茎から単離されてきた抗菌活性物質の 量と比へ，花托中に特異的に存在している可能性が考え られる.ヒマワリの未利用部位である花托を, 天然抗菌 物質として食品添加物等に有効利用することが可能に なった。

\section{要 約}

ヒマワリ (Helianthus annuus L.) の根, 茎, 葉及び花 托のエタノール抽出物から Bligh-Dyer 法により脂溶性 画分を得た. 得られた脂溶性画分の抗菌活性はEscherichia coli 及び Cladosporium herbarum を用いてペー パーディスク法により測定された，花托の脂溶性画分に
Table 5. ${ }^{13} \mathrm{C}-\mathrm{NMR}$ Spectral Data of $4\left(\mathrm{CDCl}_{3}\right)$

\begin{tabular}{|c|c|c|}
\hline Carbon & 4 & DEPT \\
\hline C- 1 & 39.95 & $\mathrm{CH}_{2}$ \\
\hline C- 2 & 19.64 & $\mathrm{CH}_{2}$ \\
\hline C- 3 & 38.01 & $\mathrm{CH}_{2}$ \\
\hline C- 4 & $44.08^{\mathrm{a}}$ & $\mathrm{C}$ \\
\hline C- 5 & 57.41 & $\mathrm{CH}$ \\
\hline C- 6 & 22.00 & $\mathrm{CH}_{2}$ \\
\hline C. 7 & 38.40 & $\mathrm{CH}_{2}$ \\
\hline C- 8 & 49.54 & $\mathrm{C}$ \\
\hline C- 9 & 52.65 & $\mathrm{CH}$ \\
\hline C-10 & 38.37 & $\mathrm{C}$ \\
\hline C-11 & 20.86 & $\mathrm{CH}_{2}$ \\
\hline C-12 & 33.52 & $\mathrm{CH}_{2}$ \\
\hline C-13 & $44.13^{\mathrm{a}}$ & $\mathrm{C}$ \\
\hline C-14 & 61.44 & $\mathrm{CH}_{2}$ \\
\hline C-15 & $135.24^{\mathrm{b}}$ & $\mathrm{CH}$ \\
\hline C-16 & $136.96^{\mathrm{b}}$ & $\mathrm{CH}$ \\
\hline C-17 & $29.56^{c}$ & $\mathrm{CH}_{3}$ \\
\hline C-18 & $25.34^{\mathrm{c}}$ & $\mathrm{CH}_{3}$ \\
\hline C-19 & 183.18 & $\mathrm{C}$ \\
\hline C-20 & 14.25 & $\mathrm{CH}_{3}$ \\
\hline
\end{tabular}

a, b, c Interchageable assignment

比較的強い抗菌活性が示され. 花托脂溶性画分の抗菌活 性物質は, カラムクロマトグラフィー, 薄層クロマトグ ラフィー(TLC) 及び $15 \% \mathrm{AgNO}_{3}-\mathrm{TLC} に よ り 4$ 種類 $(1,2,3,4)$ に単離・精製された. これらの化合物を赤外 吸光光度計, 高分解能質量分析計及び NMR を用いて構 造解析を行った. その結果, 4 種類の化合物と屯分子量 302 , 分子式 $\mathrm{C}_{20} \mathrm{H}_{30} \mathrm{O}_{2}$ を示し, 一つ (1) は五環性ジテル ペン酸である trachyloban-19-oic acid，あう一つ(2)は 四環性ジテルペン酸である kaur-16-en-19-oic acid と同 定された. 4 は beyer-15-en-19-oic acid と推定された.

\section{文献}

1）星川清親：“栽培植物の起源と伝播” p. 178～179 (1987) 二宮書店.

2) Pyrek, J. St.: Tetrahedron 26, 5,029 5,032 (1970).

3) Kasprzyk, Z., Janiszowska, W., Papaj, M.: Bull. Acad. Pol. Sci. 22, 1 4 (1973)

4) Mitscher, L. A., Rao, G. S. R., Veysoglu, T., Dralke, S., Haas, T.: J. Nat. Prod. 46, 745 746 (1983).

5) Waiss, A. C. Jr., Chan, B. G., Elliger, C. A., Garrett, V. H. Naturwissenschaften 64, 341 (1977).

6) Spring, O., Albert, K., Gradman, W.: Phytochemistry 20, 1,883 1,885 (1981).

7) Spring, O., Albert, K., Hager, A.: ibid. 21, 2,551 2,553 (1982).

8) Spring, O., Kupka, J., Maier, B., Hager, A.: Z. Naturforsch. 37, 1,087 (1982).

9) Bligh, E. G., Dyer, W. J.: Can. J. Biochem. Physiol. 37, 
$991 \sim 917$ (1959).

10) Schlenk, H., Gellerman, J. L.: Anal. Chem. 32, 1,412 1,414 (1960).

11) Cory, R. M., Stothers, J. B.: Org. Magn. Reson. 11, 252 256 (1978).

12) Arnone, A., Mondelli, R., Pyrek, J. St.: Org. Magn.
Reson. 12, 429 431 (1979).

13) Uto, S.: J. Sci. Hiroshima Univ. Ser. A 43, 97 106 (1979).

14) Fukuyama, Y., Toyota, M., Asakawa, Y.: Phytochemistry 27, 1,425 1,427 (1988).

15) Tan, R. X., Hu, Y. H., Liu, Z. L., Pan, X.: J. Nat. Prod. 56, 1,917 1,922 (1993). 